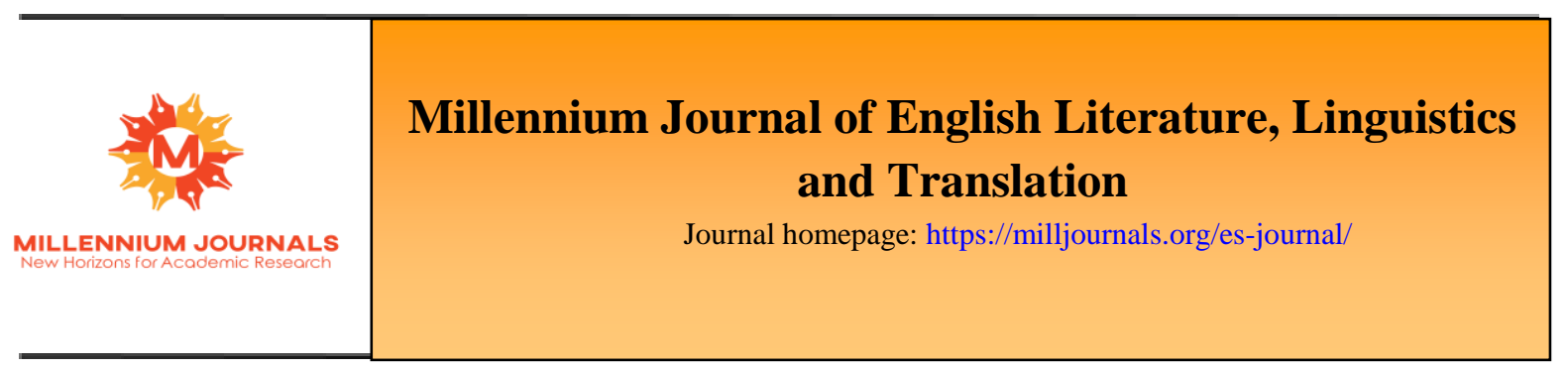

\title{
Masculine Female and Feminine Male: A Study of Gender Slippage Amid Migration Spaces in Mohsin Hamid's Exit West
}

\author{
Mahin Wahla \\ Bahauddin Zakariya University, Pakistan \\ Saiqa Imtiaz Asif \\ Government Sadiq College Women University, Pakistan \\ https://doi.org/10.47340/mjellt.v1i1.3.2020
}

\begin{abstract}
Reviewing gender as a doing reveals how gender idiosyncrasy is framed and formed. The present study tackles gender as a discursively constructed category in Mohsin Hamid's novel, Exit West (2017). Employing theoretical ideas from Butler's Gender Trouble (1999) and Bodies That Matter (2003), this qualitative descriptive study analyzes the performative nature of gender. It exposes the constraints which the normative matrix of binaries inflicts on sex, gender, and desire of Muslim migrant and refugee characters living in non-Muslim spaces. Moreover, the paper investigates the role of religion, ethnicity, and cross-national gender differences in instilling dominant gender discourses in the minds of the migrants. The findings of this study reveal that the characters produce alternative discourses of agency, transformation and voluntarism against hegemonic gender norms while relying heavily on the processes of gender slippage and role reversal.
\end{abstract}

Keywords: gender, Exit West, Butler, gender slippage, migrants

\section{Introduction}

The purpose of the present article is to examine gender identity as variegated and performative "doing" in Exit West (2017) written by a Pakistani-born English writer; Mohsin Hamid. In general, performance, theatricality, and doing have infiltrated the entire text of Exit West, confirming Judith Butler's claim that 'the doing is everything' in due course. The idea of 'the doing is everything' insinuates to both Nietzsche's On the Genealogy of Morals and Butler's Gender Trouble. Nevertheless, according to Salih (2002), it is a faulty to argue that there is no doer at all behind 'doing' since Butler has not disavowed the very idea regarding influenced performer's subsistence. 
Adopting the philosophical notion that identity is performative, this article analyzes Hamid's Exit West in terms of the fluidity of gender identity which is established through a set of performances. Exit West is the novel by the author of Reluctant Fundamentalist (2007); Mohsin Hamid. While Exit West begins as a seemingly straightforward tale about a couple living in a city swollen with camps, ultimately it is revealed as a performative treatise about the life of migrants itself. In such displaced and confined moments of migration, the novel breaks down and interrogates cultural constructions and brings into focus both the forces that are benefitted and exploited by these assumptions.

\section{Literature Review}

Gender is all about choosing between masculinity and femininity. As personality does not have settled status, it is unendingly made and reproduced; comparably, gender roles can likewise be subverted (Butler, 1999). Hamoody's and Fejer's (2018) application of Judith Butler concept of the 'performative' identity on Margaret Atwood's novel Cat's Eye is in agreement with the premises of the present study, questioning the woman's place in a patriarchal society. In addition, Hamoody and Fejer (2018) "not only determined the extent to which gender performativity determines the character's identity but also illustrated how gender identity is unstable and constructed socially and culturally" (p.161). Likewise, it can be said that individuals learn and are influenced by others, as well as, we can influence others in return (Whorf, 1997, p. 448). In their article, "Gender, Performativity, and Agency in Virginia Woolf: A Butlerian Reading of Orlando," Sadjadi and Hozhabri (2019) attempt to closely study Virginia Woolf's Orlando in terms of Judith Butler's concepts of gender, performativity, and agency to examine women's "struggles and positions in literary history, and their needs for independence" (p. 1). As per Butler's poststructuralist approach to the analysis of identity, Sadjadi and Hozhabri conclude, "there is a confluence between the development of Woolf's female characters in the novel and Butler's critical notion concerning the subject's attempts to present performativity in the form of an active agent" (p. 1). Endorsing the similar ideas in "Performing Female Identities: Gender Performativity in Charlotte Brontë's Villette", Lind-Olsen (2016) argues "what gives Villette its subversive potential is the 'doubleness' that Brontë uses when describing characters and scenes, as well as when she constructs her narrative" (p. 1). To support the Butlerian argument, Lind-Olsen (2016) investigates "how several Brontë critics claim that the theatricality that permeates the entire novel served to subvert generally established ideas about female identity found in the 19th Century" (p. 1).

Moreover, in "The Eternal Rehearsal: Judith Butler's Gender Performativity in Wilkie Collins, Sarah Waters, and Tana French," Slezek compares "Collins's experimentation with gender with regard to women's fashion to that of Sarah Waters, a modern Welsh novelist writing Victorianera historical fictions, plus two of Tana French mysteries, In the Woods and The Likeness" (2019, p. 1). Moving across chronological periods, Slezekargues that "all of the authors and texts reveal the inherent and dangerous power of gender regulations within performance" (2019, p. 1). Furthermore, similar performative regulations have been traced by Nikandam (2012) in his article, "Gender is Performative in Illusive Beliefs," using Butler's notion of gender as performative and the example of drag queen as a way to understand the reality of female gender from unreal one. Nikandam claims, "Evelyn as female gender constructs a new subjective performativity in Angela Carter's The Passion of New Eve, Evelyn does this with his queer appearance and his transformation opens up some paths for the Third gender" (2012, p. 1). 
On the whole, extensive research has been carried out in relation to gender identity. However, as the given critical commentary suggests and to the best of my knowledge, a literary void exists in terms of studying gender as a performative entity in Pakistani English fiction in particular. For that reason, the present study aims at filling this gap by tracing performative transformation, negotiation, and reconstruction of Nadia's and Saeed's gender identity in the novel by a Pakistani English writer.

\section{Theoretical Framework}

Is gender being assigned to us? Do we simply learn it as we grow up? Are we all subjected to our contemporary norms? Why is it important? (Or alternatively) Is gender performative? If yes, how is it so? These are some of the questions Butler has addressed in Gender Trouble. Most importantly, Butler has endorsed that not only gender expression but our understanding of biological differences is also built and not something inherited/real. For that reason, these constructed biological assumptions facilitate the propagation of predetermined binary genderrelated values, judgments, and beliefs among individuals (Butler, 1999). This propagation, according to Gender Trouble, eventually turns normative structure into the most powerful matrix since so many people start believing and practising them. Though most likely, it is hard to resist a spell of normativity since deviating from the norms can get us into trouble, but Gender Trouble has claimed that hope is still there. Continuing the debate in Bodies That Matter (2003), Butler has emphasized that it is through the body that agency can be exercised. Additionally, Butler in Bodies That Matter has presumed the body is a substrate and site of gender formulation process. For that reason, the body is the boundary and constraint which an individual has to cross in order to subvert normative frameworks and thoughts. Nevertheless, quite surprisingly, the body is not only a site of oppression, but also a source of resilience - since only through bodily agency, doings, gestures, and behaviour an individual can resist the power of normativity.

According to feminists, there is a clear difference between sex and gender. Therefore, they should not be equated at any cost. For instance, sex is naturally and biologically constructed, whereas gender is a socially and culturally built attribute (Chinn, 1997). However, Butler (1999) denies this intentionally created distinction between sex and gender altogether. She has portrayed both sex and gender as societal constructions since individuals are not born having labels of man/woman with them (Butler, 1999, p. 10). The question is, why it's so? Butler has answered it beautifully by exposing the politics behind it. According to her, it's all about the dissemination of pre-existing conventions to ensure a hegemonic flow of cultural and social patterns (Butler, 1987). The most popular misconception regarding gender is that it is directly proportional to sex. For instance, it is believed by essentialists that sex exists in a form of binaries, and so does gender. Nevertheless, Butler (1999) has condemned the idea of gender imposition upon a body. Moreover, she has also established a concept of free-floating and independent gender (p. 10).

After undertaking the issue of gender-sex distinction, Butler (1999) moves forward to investigate individuals' desires, which contribute to the lion's share in their identity construction. Indeed, how a person presents his/her inner desires in terms of sexuality is significant enough in his/her individuality (p. 3). Exposing a close connection among gender, desire, and sexuality, Butler (1999) portrays gender as an outcome of an ever-going war between what a person 'desires to be' against what normative structure wants him/her to be (p. 9).On the whole, for Butler, gender and 
sex are better to be placed under a category of 'Verb' in terms of parts of speech; i.e., the grammatical status of the word 'gender' is not a noun (p. 33).

Simply, all her concerns revolve around genealogical stance regarding 'woman'. Siding with de Beauvoir's famous words regarding the societal construction of 'woman', Butler proposes that, like a woman, gender is also not an instinctive attribute, but rather an act that an individual executes. Drawing on de Beauvoir's concept of gender appropriation, Butler endorses all possibilities of cultural interference $(1999$, p. 12). In other words, to Butler, a woman can be a woman without being feminine. Butler (2003) has endorsed that gender (like the term woman) is a process, a construction and a practice which is always in the process of becoming. Therefore, it is impossible to trace its beginning and end. Being vulnerable to dominant ideologies, gender is open to intervention, the process of construction and acculturation (Butler, 1999, p. 43). Butler, nonetheless, advocates that gender is not an involuntary ingredient of an individual's identity, but something enforced upon it. In other words, Butler has put stress on the performative nature of gender identity. In Gender Trouble, Butler has claimed with certainty that there is no true identity behind the way gender is normally performed (1999, p. 33). Here, her argument overlooks the possibility of doer's dominance and proposes that deed is everything. Likewise, linguistic and philosophical writings of Nietzsche, Hegel, Derrida, Foucault, and Althusser on identity provide a solid base for Butler's claim of performativity. Certainly, it is not incorrect to conclude that the theory of performativity revolves around the aim of unearthing the forces which are behind the formulation of an individual's (gender) identity. On the whole, based on Butler's idea, Chin (1997, p. 299) has confirmed that gender is:

- A discursively constructed entity

- An ideological puppet in the hands of dominant societal discourses

- Repetitive in action

- Performative in nature

\section{Discussion and Analysis}

Turning the pages of the novel, Hamid keeps the attention of readers intact by bombarding them with a constant shift of gender values. As a case in point, while travelling from one destination to other, the expectations of Nadia and Saeed regarding attributes and gender behaviours were shaped by culture and society around them. Before migrating from their native land, Saeed and Nadia were only under commitment of fulfilling gender roles and normative responsibilities of their country of birth, but as they migrated, they found themselves sandwiched between accountability processes held by dominant discourses of the host country on one side and the country of birth on the other.

Home is a place that is not separate from society; rather, it is an essential part of it (Wahla, Mamona, \& Buriro, 2019). Nadia was badly afflicted because of contrasting restraints of a devout ideology and religiosity of a society in which she was not at home despite having one. Rebelling against societal norms, Nadia first sacrificed her family to live an independent life, and later she had to cover her body with a black robe so that she could save herself from 'male gaze. As per Nadia's reasoning, she has preferred taking hijab and black robe not because she is close to Allah or she is religious in her doings, but just to escape the annoying gazes of men. Moreover, Nadia's act of wearing black robe exposes constraints of dominant ideologies. It suggests that, as per societal 
discourses, Nadia's own independent body can only be identified well when it gets approval of being chaste from the society she was living in. It suggests that following the norms of heterosexual matrix keeps one away from confronting pre-existing ideologies and eventually from retribution. Anyhow, as her outlook has protected her from being evaluated by dominant cultural and societal discourses of her country of birth, it has also limited her autonomy and made her more vulnerable to men who took her as a weak stereotypical harmless girl on whom they could exercise their power easily. While staying in a mansion in London, on the weekend, Nadia decided to visit a nearby bank in order to withdraw money, but she was alarmed to death when she was sexually harassed by a man in a crowd while they were standing in a queue. Seeing that, Nadia was "so stunned she could not shout, or speak, reduced to clamping her thighs together and her jaws together, her mouth shutting automatically, almost physiologically, instinctively, her body sealing itself off" (Hamid, 2017, pp. 59-60). It proposes that no matter how masculine she was deep down, her stereotypical feminine outlook was still making her susceptible to sexual harassment. In addition, in the refugee camp, her black robe becomes her 'ethnic marker' and ultimately a reason for verbal harassment. The situation was relatively similar for Saeed. A Muslim male-dominated society, as depicted in the novel, believes that men's manly power lies only in his masculinity. Thus, Saeed's father's biggest wish was to see Saeed becoming "one of those manly men"; a ritual that was meant to connect Saeed not only to religious ideologies but also to an abstract conception of "behaving like a gentleman" (Hamid, 2017, p. 200).

Here it is significant to refer to the time when Saeed and Nadia were leaving their home together for the first time to avoid militants who have invaded their city. Saeed's father pleaded Nadia to comfort and take care of his son with all her heart, and he asked her to promise this to him (Hamid, 2017, p. 93). Like a submissive conformist, Nadia did migrate with Saeed while holding onto him as an 'elderly mother'. However, this is somehow an utter paradoxical situation, and irony can easily be seen on revisiting it with a different lens. According to the normative matrix, masculinity is to be associated with men only in terms of their domineering and overpowering personalities (Butler, 1999). Nevertheless, Nadia is clearly driving the seat with all the duties and promises of protecting poor Saeed. Wahla and Mamona (2017) rightly deduced that women are not entirely victims. They are equally capable of showing their strength to come out of the situation of victimization to gain power and assert their independent identity. For example, throughout the migration process, Saeed appears to be sissy, vulnerable, and entirely dependent on Nadia. When passing through a magical door for the first time, he felt frightened enough to seek refuge in Nadia by holding her tight in a hug (Hamid, 2017, p. 99). Likewise, whereas Saeed stayed at margins of all migrant groups and refugee camps so that no one would start to ask questions about their lives, however, Nadia simply knew how to place herself in a middle of the gathering, delineate her boundaries, and fashion intimacies around no-go areas (Hamid, 2017, p. 15). It suggests that Saeed has opted for avoidance as a tool to survive.

Contrary to him, Nadia has chosen to confront and fight. Unlike a scared little feminine girl of a patriarchal system, Nadia was neither worried about her virginity nor was she hysterically possessive after her man. As per researchers, 'hysteria' has a close relation with the etymological roots of femininity (Preez, 2004). According to Preez, hysteria is associated with intense, emotional, sensitive, and extremely impressionable women (pp. 47-48). However, Nadia clearly lacks such impressionability and susceptibility but somehow exhibits similar hyper-femininity. Saeed has shown traces of hysteria in closed boundaries of migratory places with a fear of getting harmed/lost 
(Preez, 2004, p. 62). In addition, Nadia's manly act of inviting Saeed at her place, disguising him as her sister, reflects Nadia's rebellious doings against normativity, which is a way too hard for a woman to display in a patriarchal society. However, it also throws light on Saeed's passive personality since he has disguised himself as a female, carrying out femininity. For this reason, by exaggerating those standards, he mimics gender against the demands of context in which he lives. This conscious enacting makes Saeed experience gender slippage.

Throughout the novel, Nadia keeps reversing the roles as she consciously makes a performance out of gender and exposes the constructed nature of gender in the first place. Her typical manner, throughout the first half of the novel, comprises those strenuous advances which in a patriarchal setup are associated with masculinity/men. For a case in point, Saeed does not want to have sex until their wedding night, but Nadia insists on not only doing but also repeating an act despite knowing religious and cultural repercussions of doing so. It seemed that she has been enjoying a game in which she holds all the power. Dominating in bed, she is carnal and motivating (Hamid, 2017, p. 12). Taking the lead in bed, she clearly overthrows the clichéd concept of phallic dominancy. Under a guise of her chaste outlook, she does all the deeds which are normally thought to be masculine. However, by doing so; Nadia promotes a fluid nature of gender. She provides compelling examples of demeaning the binary system by dominating in her sexual relationships with women as well. Later in the course of migration, readers can see an aggressive annihilation of Nadia's femininity and her transformation into a lesbian.

Nadia's lesbian needs get their way out on meeting with a young girl in Marakesh. Nadia always feels attracted to her, and they both used to enjoy good times. On departing, they even make promises to meet each again one day. Later during her stay in another place, Nadia gets chills all over her body on recalling her memories with her (Hamid, 2017, p. 123). Additionally, we are told that she is the first girl who has made her heart flutter (Hamid, 2017, p. 77). Moreover, during her stay in Marin, her strong homosexual instincts get evident in her relationship with the female cook since Nadia seems to be totally mesmerized by the lady chef (Hamid, 2017, p. 180). She stares at her muscles with desperation in her eyes. If we discuss the very reason why Nadia undergoes such a huge shift in gender, it clearly takes us to the distant relationship between Saeed and Nadia. After migrating, their relationship weakens. We see them stand beside one another, talking only between songs (Hamid, 2017, p. 216). However, earlier, they find excuses to develop their intimacies in a way or other. It seems that Saeed's inability to attend to Nadia properly triggers her interest in females. Since Nadia is a woman with a big sexual appetite and because she does not get it satisfied, she starts projecting her feelings onto the women who are available to her within migration spaces. Furthermore, another way of seeing things is to take Nadia, not as a homosexual by birth, but her homosexual undertones are somehow a by-product of Saeed's unavailability to satisfy her sexual desires. Duane rightly compares gender with a mask/veil which is worn/removed depending on circumstances (1982, p. 81).

On the whole, the performative acts of Nadia and Saeed encompass gender play dressing, role-playing, and reversals. The purpose of exploring instances of gender slippage in the novel is to show how enclosed migration spaces help the female protagonist (Nadia) in her performative tasks that are conventionally linked with masculinity. Indeed, there is nothing wrong to stick to rules which the individual personally thinks are important to be accepted, but Butler's idea of gender performance puts such an attitude under the column of enforced patterns of the normative matrix 
that holds back an individual from doing his/her inner desire. Generally, the significance of gender space in Exit West suggests that the novel is constructed around an idea of breaking in/out of 'assigned' role that somehow highlights the discursive and performative nature of gender.

\section{Conclusion}

To conclude, in Hamid's novel, gender emerges as fluid, performative, and uncertain entity helping the characters in subverting the normative matrix. Unlike Saeed, Nadia had produced alternative discourses of resistance and transformation when she experienced gender slippage while resisting dominant discourses of the normative matrix by preferring her queer orientation over normative rules of femininity. Nadia, in her driving role, is more likely to be perceived as agentic or performative under the influence of masculine agency. To put it in other words, the intrepid domination of Nadia is patently in agreement with masculinity because she lacked feminine agency. Similarly, she portrayed the character of a girl who was a true symbol of the dominant discourse in the unknown country of her origin; conversely, she went through gender slippage over time.

Simply put Nadia's typical manner, throughout the first half of the novel, comprises those strenuous role reversal advances through which readers can see Nadia's sex drive in her illegitimate relationships with dozen of men, including Saeed and the musician. However, the next half of the novel has shed light on Nadia's doing of slipping from the track of heterogeneity while taking refuge in her lesbian instinct in her relationships with the girl in Mykonos and the female cook at Marin. On the whole, the experiences Nadia had been through in territorial spaces of migration suggest that Exit West is built around broken images of breaking in/out through processes of gender slippage. The negotiation of gender space in terms of gender slippage thus becomes a central motif of the chapter of discussion and analysis. Hence the apparent emblematic masculinization of Nadia is probed in terms of necessary examples which she has provided to dismantle rigid and binary gender and sexual categories, consequently subverting the normative matrix.

As far as the process of initiating alternative discourses is concerned in case of Saeed, he redefined the concept of masculinity to man and femininity to female only as he experienced slippage in gender as a result of overdoing femininity in the migration processes. He awaited an erotic fulfilment that entailed dissolution of boundaries of self and thorough subversion of conventional gender codes, which eventually constrained mobility of his sexual desires and varieties of genital behaviours. The powerlessness of Saeed during the course of migration has suggested aversion of phallic penetration which was ironically offset by erotic expectations. To add, he was offered a feminine form but a masculine penetration. Thus his negotiated performances of gender are evident in the acquirement of sexual passivity as per norms and prescriptions of femininity. Briefly, in Exit West (2017) Hamid's employment of love trap (for Saeed) and spatial captivity (during his constant phase of displacement) has inverted an old convention of depicting heroine as a poor dependent being and explored a notion of masculine captivity thus highlighting the fact, 'the doing is everything.'

\section{References}

[1] Ahmed, L. (1992). Women and Gender in Islam: Historical Roots of a Modern Debate. Yale University Press. 
[2] Akcesme, B. I. (2010). Comparative discourse analyses of gender construction in the novels of Robert Heinlein, Ursula Le Guin, Joanna Russ and Samuel Delany [Unpublished master's thesis]. Middle East Technical University.

[3] Beauvoir, S. (2009). The second sex. Alfred A. Knop.

[4] Budney, C. A. (2017). The refugee and forced migration bildungsroman: Coming of age and coming into form through fictions of home and exile [Unpublished Doctoral dissertation]. University of California, Berkeley.

[5] Butler, J. (1999). Gender trouble: Feminism and the subversion of identity. Routledge.

[6] Butler, J. (2003). Bodies that matter: On the discursive limits of 'sex'. Routledge.

[7] Chinn, S. E. (1997). Gender performativity. In A. Medhurst, \&S. R. Munt (Eds.), Lesbian and gay studies: A critical introduction (pp. 294-308). Cassell.

[8] Claeys, S. (2007). How to do things with Butler: An inquiry on the origin, citation and application of Judith Butler's theory of performativity [Unpublished Doctoral dissertation]. Universiteit Gent Faculteit Letteren en Wijsbegeerte.

[9] Derrida, J. (1988). Signature event context. Northwestern University Press.

[10] Doane, M. A. (1982). Film and the masquerade: Theorizing the female spectator. Screen, 3(4), 74-88.

[11] Feinstein, E., \&The Women's Theatre Group. (2000). Lear's daughters. In F. Daniel, \& F. Mark (Eds.), Adaptations of Shakespeare: A critical anthology of plays from the seventeenth century to the present (pp. 217-232). Routledge.

[12] Foucault, M. (1980). The History of sexuality (Vol. 1). Random House

[13] Hamid, M. (2017). Exit West. Penguin Random House.

[14] Hamoody, H. D., \& Fejer, N. A. (2018). Identity and performance in Margaret Atwood novel cat's eye. International Journal of Humanities and Social Sciences, 8(1), 161-169.

[15] Lind-Olsen, Elin. (2016). Performing female identities: Gender performativity in Charlotte Brontë's Villette. [Unpublished master's thesis]. Arctic University of Norway.

[16] Marecek, J., Crawford, M., \& Popp, D. (2004). On the construction of gender, sex, and sexualities. In A. Eagly, A. E. Beall, \& R. J. Sternberg (Eds.), The psychology of gender (pp. 192-216). Guilford Press.

[17] Nikandam, R. (2012). Gender is performative in illusive beliefs. English Language and Literature Studies, 2(2), (pp. 84-88). http://doi:10.5539/ells.v2n2p84

[18] Nolin, C. (2006). Transnational ruptures: Gender and forced migration. Ashgate Publishing.

[19] Preez, A. (2004). Putting on appearances: Mimetic representations of hysteria. De Arte, 69(1), $47-61$. 
[20] Sadjadi, B., \&Hozhabri, S. (2019). Gender, performativity, and agency in Virginia Woolf: A Butlerian reading of Orlando. Khazar Journal of Humanities and Social Sciences, 22(4), 5 23. http://doi10.5782/2223-2621.2019.22.4.5 5

[21] Salih, S. (2002). Judith Butler. Routledge.

[22] Slezek, J. (2018). The Eternal rehearsal: Judith Butler's gender performativity in Wilkie Collins, Sarah Waters, and Tana French. Honors Theses. https://digitalworks.union.edu/theses/1697

[23] Wahla, M., \&Mamona, M. (2017). When I raised my eyes again: Women's journey to gain power in Sidhwa's ice-candy man. Journal of English Language and Literature, 8(1), 590594. http://doi10.17722/jell.v8i1.230

[24] Wahla, M., Mamona, \&Buriro, A. A. (2019). Language and gender construction: Stereotypes and identity reconstruction in a doll's house: A sociolinguistic perspective. The Women, 11(11), 104-115. http://search.ebscohost.com/login.aspx?direct=true \&site=edslive \&db=asn\&AN=13842704 $4 \&$ custid $=$ s 8280428

[25] Whorf, B. J., (1997). The relation of habitual thought and behavior to language. In Coupland, N., \& Jaworski, A. (Eds.). Sociolinguistics: A reader and coursebook (pp. 443-463). Macmillan Publishers Limited. 